\title{
Effect of Various Grades of Exercise on Serum Cortisol
}

\author{
TriptiTripathi $^{1}$, SonaliSaxena ${ }^{2}$, Saurabh Saha ${ }^{3}$, JalajSaxena ${ }^{4}$, \\ Dolly Rastogi $^{5}$, Chitra Srivastava ${ }^{6}$, Preeti Kanowjia ${ }^{7}$ \\ ${ }^{1}$ Assistant Professor (Physiology), ${ }^{2}$ Associate Professor (Medicine), ${ }^{3}$ Associate Professor (Physiology), ${ }^{4}$ Professor \\ $\&$ Head (Physiology), ${ }^{5}$ Professor (Physiology), ${ }^{6}$ Associate Professor (Physiology), ${ }^{7}$ Assistant Professor \\ (Physiology), Department of Physiology, G.S.V.M. Medical College, Kanpur.
}

\begin{abstract}
Increasing incidence and prevalence of chronic diseases are mostly due to improving socio-economic status and changes in modern lifestyles, including diets which are high in salt, sugar, and undesirable fats and decrease in physical activity levels in Indian population. The present study evaluates the effect of various grades of exercise on serum cortisol in healthy young Indian adults. The objective of the study was to evaluate the pre and post exercise changes in serum cortisol levels. A total 56 healthy First year MBBS student's age between 18-27 yrs of either sex were taken at G.S.V.M. Medical College Kanpur. The subjects were treated with moderate and heavy exercise. Pre-exercise determination of serum total cortisol of all the subjects was done. Post-exercise determination of serum total cortisol of all the subjects after duration of one week and 12 weeks of exercise was done. After completion of 12 weeks of exercise a comparison was made between pre and post exercise values of total serum cortisol. Statistical Analysis was done by paired student ' $t$ ' test and $95 \%$ level of confidence was taken significant $(\mathrm{p}<0.05)$. Results indicated that Serum cortisol varies with different grades of exercise and there was slight increase in serum cortisol concentration after moderate exercise but it was of not very much significance. There are some divergent findings also and most literature has cited that an approximate $60 \%$ exercise intensity threshold is necessary to elicit a significant increase in blood cortisol.Thus, according to our study, there is correlation of the serum cortisol levels according to the different grades of exercise.
\end{abstract}

Keywords: Serum Cortisol, Exercise.

\section{Introduction}

Physical exercises prevent aging, strengthen muscles and the cardiovascular system, help in weight loss and boost the immune system and helps prevent "diseases of affluence" such as cardiovascular disease, type 2 diabetes and obesity Stampfer M J et al(2000 ${ }^{[1]}$. The physical exercises may be aerobic and anaerobic. The dynamic and static terms are also used in physical exercise. Many other terms such as light, moderate/

\footnotetext{
Corresponding Author:

Dr. Saurabh Saha

Associate Professor, Department of Physiology, G.S.V.M. Medical College, Kanpur

e-mail:drsahagsvm@gmail.com
}

mild and severe/vigorous exercise have also been used depending upon the energy intake by Carol Ewing Garber $(2011)^{[2]}$.

Cortisol, a 21 -carbon steroid hormone, the main glucocorticoid form in humans, is a catabolic hormone secreted from the adrenal cortex in response to physical and psychological stress. Cortisol is produced in the human body by the adrenal gland in the zona fasciculata, the second of three layers comprising the adrenal cortex. The cortex forms the outer "bark" of each adrenal gland, situated atop the kidneys.

Of all the cortisol about $70 \%$ is bound to cortisol binding globulin, $20 \%$ to albumin and the rest is free. The free cortisol is the biologically active form with a half life of 30-90 minutes. Secretion of cortisol is controlled by the hypothalamus and the pituitary gland, 
parts of the brain that are important in many other body functions as ascertained byBurtis A et al(2013 $)^{[3]}$.

In response to the stress of exercise, cortisol plays many roles in helping the body to modify and adapt to the stress. It also includes: the mobilization of free fatty acids (FFA) from adipose tissue, protein catabolism, stimulation of gluconeogenesis at the liver, and inhibition of glucose uptake by the working skeletal muscle by Brooks et al $(2000)^{[4]}$. All these responses increase the exercise capacity and aid in recovery and adaptation Viru et al (2007) ${ }^{[5]}$. There is a "threshold intensity" resulting in significant elevations in circulating cortisol. In one such study by Davies et al(1973) ${ }^{[6]}$ observed that an exercise intensity of $50-60 \%$ of VO2max must be reached for cortisol to be increased and the absolute levels attained during exercise are dependent on the total duration of the exercise bout.

Cortisol increases alternate fuels for muscle, such as fatty acids and amino acids (from muscle amino acid stores and protein catabolism), impairs glucose entry into skeletal muscle, and supplies the fuels (amino acids) for the liver to increase glucose production. All these functions are increased during times of low body carbohydrate nutrition, such as when blood glucose falls. Thus, when doing prolonged aerobic exercise, the muscle catabolic effects of cortisol can be diminished simply by maintaining blood glucose, which in turn is best done through the ingestion of carbohydrate (liquid and/or solid).

\section{Materials and Method}

The present study was carried out on 56 Subjects including 28 males and 28 female students of $1^{\text {st }}$ year M.B.B.S in the Department of Physiology at G.S.V.M. Medical College, Kanpur. This cross sectional pilot study include 18 to 27 years old students. All the physical parameters like age (years), Height (cms), Weight (Kgs) and blood pressure ( $\mathrm{mm} \mathrm{Hg}$ ) were recorded initially in all subjects. The subjects were told about the study and their written consent was taken.

The subjects were also divided into two groups based on BMI (Body Mass Index) to see, if there exit any correlation between the serum cortisol and BMI.

After subject characteristics were assessed, they were instructed to warm-up on the by cycle ergometer for 5 minutes at a very light workload. At this time, the seat height was adjusted to the optimal height and comfort. The light warms up was followed up by 5 minutes of stretching, primarily emphasizing the torso and the lower extremities. The subject was subsequently properly fit with a mouthpiece and oxygen uptake which was used to make sure that the values were normal and the metabolic system was functioning properly.

The workload was then increased at the end of the 3 minute intervals (stages) until volitional fatigue. The target of the exercise was to achieve a heart rate 125 130 beats/minute (severe exercise) and it was achieved in 10 to 15 minutes by doing the cycling without any extra load. The brink of exhaustion after 10 minutes of exercise was taken as end point of the exercise for that subject.

The baseline readings of total serum cortisol and serum total protein were taken before exercise. The subjects were then asked to do various grades of exercise on alternate day basis under supervision. Total serum cortisol and total serum proteins were then measured followed by measurement of the total serum cortisol after exercise.

The reported workloads were mean values calculated over the duration of the 30 minutes of exercise.

The subjects were divided into two groups after defining their body mass index (BMI) and classified as

Non-obese group with $\mathbf{B M I}<25 \mathrm{~kg} / \mathrm{m}^{2}$

Obese group with BMI $\geq 25 \mathrm{~kg} / \mathrm{m}^{2}$

The first blood samples $(3 \mathrm{~mL})$ as baseline, after placement of a catheter, were collected using a 3-cc syringe (Vanishpoint) and a 25 gauge needle (Retractable Technologies, Inc., TX, USA) in the morning between 9 a.m.- 2.00 p.m.

The plasma was pipetted into cryo-freeze tubes and stored at $-80^{\circ} \mathrm{C}$ degrees Celsius in an ultra freezer.

After the blood sample was taken, subjects were allowed to actively cool down on the cycle ergometer, followed by a resting period. After 30 minutes recovery post-exercise, moderate and severe exercise were done by subjects with Heart rate (HR) reaching $>25 \pm 50$ and $>50$ respectively of the baseline HR. Then last blood samples were collected.

Total serum cortisol was measured using Enzyme linked immunosorbent assay (ELISA) at the Department 
of Pathology, G.S.V.M. Medical College Kanpur. The cortisol ELISA kit was used for the quantitative in vitro diagnostic measurement of cortisol in the serum. The cortisol ELISA kit is a solid phase Enzyme-linked immunosorbent assay (ELISA), based on the principle of competitive binding.

The significance of the standard errors of means between the different sets of observations have been assessed by applying paired student ' $\mathrm{t}$ ' test and $95 \%$ level of confidence $(\mathrm{p}<0.05)$.

\section{Observations and Results}

These investigations were made on fifty six medical students (28 males and 28 females) out of 190 M.B.B.S. students who volunteered for this study as subjects. The age of subjects ranged from 18-27 years. Pre-exercise determination of serum total cortisol of all the subjects was done before the training was started. The baseline data of each subject was recorded. Post-exercise determination of serum total cortisol of all the subjects after duration of one week and 12 weeks of exercise was done. After completion of 12 weeks of exercise a comparison was made between pre and post exercise values of total serum cortisol.

The pre (baseline) and post exercise (moderate and severe) serum cortisol concentration (ng/dL) of all subjects is summarised in Table showed that the mean serum cortisol increased after moderate exercise while it decreased after severe exercise as compared to baseline. Comparing the mean serum cortisol level of the three groups (baseline, after moderate exercise and severe exercise), ANOVA showed significantly different serum cortisol level among the groups $(\mathrm{F}=3.82, \mathrm{p}<0.05)$.

Further, comparing the mean serum cortisol level between the groups, Student ' $t$ ' test and Tukey test showed similar serum cortisol level after moderate exercise $(7.79 \pm 0.28$ vs. $8.13 \pm 0.28$, mean difference $=0.34, \mathrm{q}=1.19, \mathrm{p}>0.05$ ) and severe exercise $(7.79 \pm 0.28$ vs. $7.04 \pm 0.29$, mean difference $=0.75$, $\mathrm{q}=2.63, \mathrm{p}>0.05$ ) as compared to baseline though it was increased $4.2 \%$ and decreased $9.6 \%$ respectively (Table 7 and Fig. 15). However, the mean serum cortisol level decrease (13.4\%) significantly after severe exercise as compared to after moderate exercise $(8.13 \pm 0.28$ vs. $7.04 \pm 0.29$, mean difference $=1.09, \mathrm{q}=3.82, \mathrm{p}<0.05)$.

The mean serum cortisol level over the periods/ groups were also compared according to gender and summarised in Table 1. After exercise, the mean serum cortisol level decreased in females while it was increased in males. Comparing the mean serum cortisol level between the periods, Student ' $t$ ' test and Tukey test showed significant $(p<0.05$ or $p<0.01)$ decrease in serum cortisol level in females at severe exercise as compared to both baseline and moderate exercise while in males it did not differed significantly $(\mathrm{p}<0.05)$ (Table). Comparing the mean serum cortisol level between the genders, Student ' $\mathrm{t}$ ' test and Tukey test showed significantly $(p<0.05$ or $p<0.001)$ different and higher serum cortisol level in males as compared to females at both moderate and severe exercise while it did not differ $(p>0.05)$ at baseline i.e. found to be statistically the same.

\section{Table 1: Pre and post exercise serum cortisol concentration (ng/dL) of all the subjects}

\begin{tabular}{|l|c|c|c|}
\hline Groups/Periods & $\begin{array}{c}\text { Mean } \pm \text { SE } \\
(\mathbf{n}=\mathbf{5 6})\end{array}$ & F value & P Value \\
\hline Baseline & $7.79 \pm 0.28$ & 3.82 & $<0.05$ \\
\hline After moderate exercise & $8.13 \pm 0.28$ & \multirow{2}{*}{3.82} & $<0.05$ \\
\cline { 1 - 2 } After severe exercise & $7.04 \pm 0.29$ & & \\
\hline
\end{tabular}

Table 2 : Pre and post exercise serum cortisol level $(\mathrm{ng} / \mathrm{dL})($ Mean $\pm \mathrm{SE})$ according to gender

\begin{tabular}{|l|c|c|c|}
\hline Groups/Periods & $\begin{array}{c}\text { Female } \\
(\mathbf{n = 2 8})\end{array}$ & $\begin{array}{c}\text { Male } \\
(\mathbf{n = 2 8})\end{array}$ & p value \\
\hline Baseline & $7.72 \pm 0.37$ & $7.87 \pm 0.42$ & 1.000 \\
\hline After moderate exercise & $7.28 \pm 0.41$ & $8.99 \pm 0.33$ & 0.015 \\
\hline After severe exercise & $5.82 \pm 0.33$ & $8.27 \pm 0.36$ & $<0.001$ \\
\hline
\end{tabular}

Table 3: Correlation (r value) between basic characteristics and outcome measures at three different periods $(n=56)$

\begin{tabular}{|l|c|c|c|c|c|c|}
\hline \multirow{2}{*}{$\begin{array}{l}\text { Basic } \\
\text { characteristics }\end{array}$} & \multicolumn{3}{|c|}{ Heart rate (beats/min) } & \multicolumn{3}{c|}{ Serum cortisol concentration (ng/dL) } \\
\cline { 2 - 7 } & Baseline & Moderateexercise & Severeexersice & Baseline & Moderateexercise & Severeexercise \\
\hline Age (yrs) & $-0.07^{\mathrm{ns}}$ & $0.01^{\mathrm{ns}}$ & $-0.04^{\mathrm{ns}}$ & $-0.17^{\mathrm{ns}}$ & $0.15^{\mathrm{ns}}$ & $0.09^{\mathrm{ns}}$ \\
\hline Sex & $-0.23^{\mathrm{ns}}$ & $-0.26^{\mathrm{ns}}$ & $-0.11^{\mathrm{ns}}$ & $0.04^{\mathrm{ns}}$ & $0.41^{* *}$ & $0.56^{* * *}$ \\
\hline
\end{tabular}




\begin{tabular}{|l|c|c|c|c|c|c|}
\hline \multirow{2}{*}{$\begin{array}{l}\text { Basic } \\
\text { characteristics }\end{array}$} & \multicolumn{3}{|c|}{ Heart rate (beats/min) } & \multicolumn{2}{c|}{ Serum cortisol concentration (ng/dL) } \\
\cline { 2 - 7 } & Baseline & Moderateexercise & Severeexersice & Baseline & Moderateexercise & Severeexercise \\
\hline Height $(\mathrm{cm})$ & $-0.03^{\mathrm{ns}}$ & $-0.03^{\mathrm{ns}}$ & $0.04^{\mathrm{ns}}$ & $0.02^{\mathrm{ns}}$ & $0.37^{* *}$ & $0.30^{*}$ \\
\hline Weight $(\mathrm{kg})$ & $-0.05^{\mathrm{ns}}$ & $-0.10^{\mathrm{ns}}$ & $-0.03^{\mathrm{ns}}$ & $-0.12^{\mathrm{ns}}$ & $0.19^{\mathrm{ns}}$ & $0.21^{\mathrm{ns}}$ \\
\hline BMI $\left(\mathrm{kg} / \mathrm{m}^{2}\right)$ & $-0.03^{\mathrm{ns}}$ & $-0.12^{\mathrm{ns}}$ & $-0.09^{\mathrm{ns}}$ & $-0.18^{\mathrm{ns}}$ & $-0.11^{\mathrm{ns}}$ & $-0.01^{\mathrm{ns}}$ \\
\hline SBP $(\mathrm{mmHg})$ & $-0.15^{\mathrm{ns}}$ & $-0.06^{\mathrm{ns}}$ & $0.09^{\mathrm{ns}}$ & $-0.01^{\mathrm{nd}}$ & $-0.02^{\mathrm{ns}}$ & $0.20^{\mathrm{ns}}$ \\
\hline DBP $(\mathrm{mmHg})$ & $-0.24^{\mathrm{ns}}$ & $-0.16^{\mathrm{ns}}$ & $0.10^{\mathrm{ns}}$ & $-0.25^{\text {nd }}$ & $-0.13^{\mathrm{ns}}$ & $0.09^{\mathrm{ns}}$ \\
\hline
\end{tabular}

ns- $\mathrm{p}>0.05,{ }^{*}$ - $\mathrm{p}<0.05, * *_{-} \mathrm{p}<0.01, * * *_{-} \mathrm{p}<0.001$

\section{Serum cortisol concentration (ng/dL)}

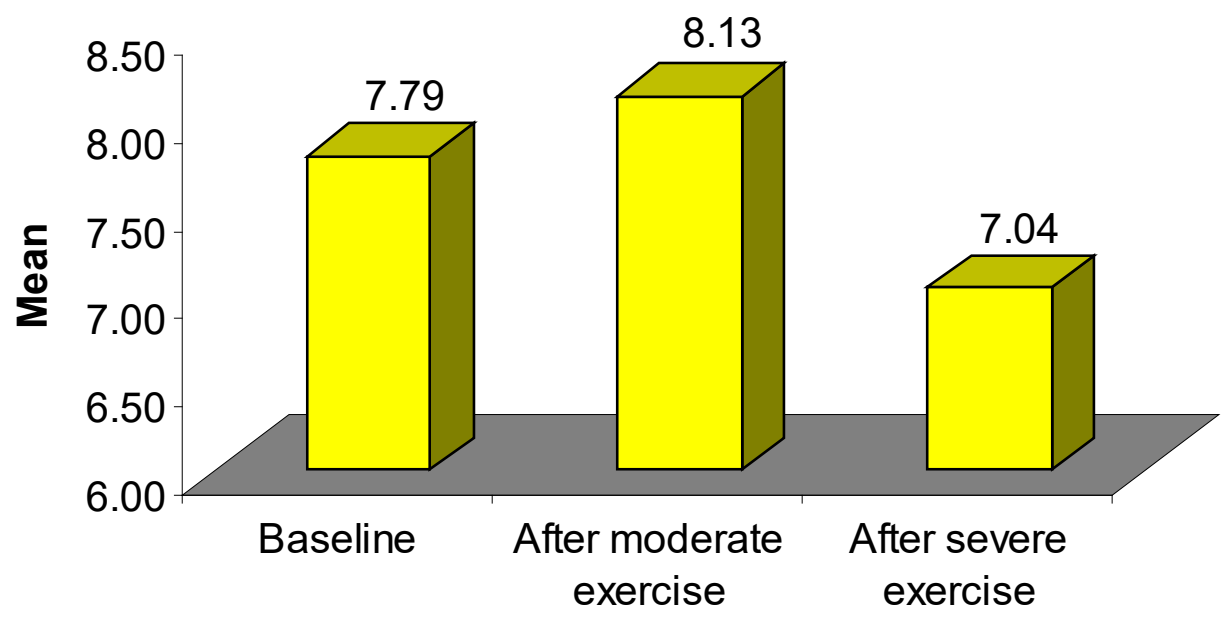

Figure 1. Comparison of mean serum cortisol level between two group

\section{Serum cortisol concentration (ng/dL)}

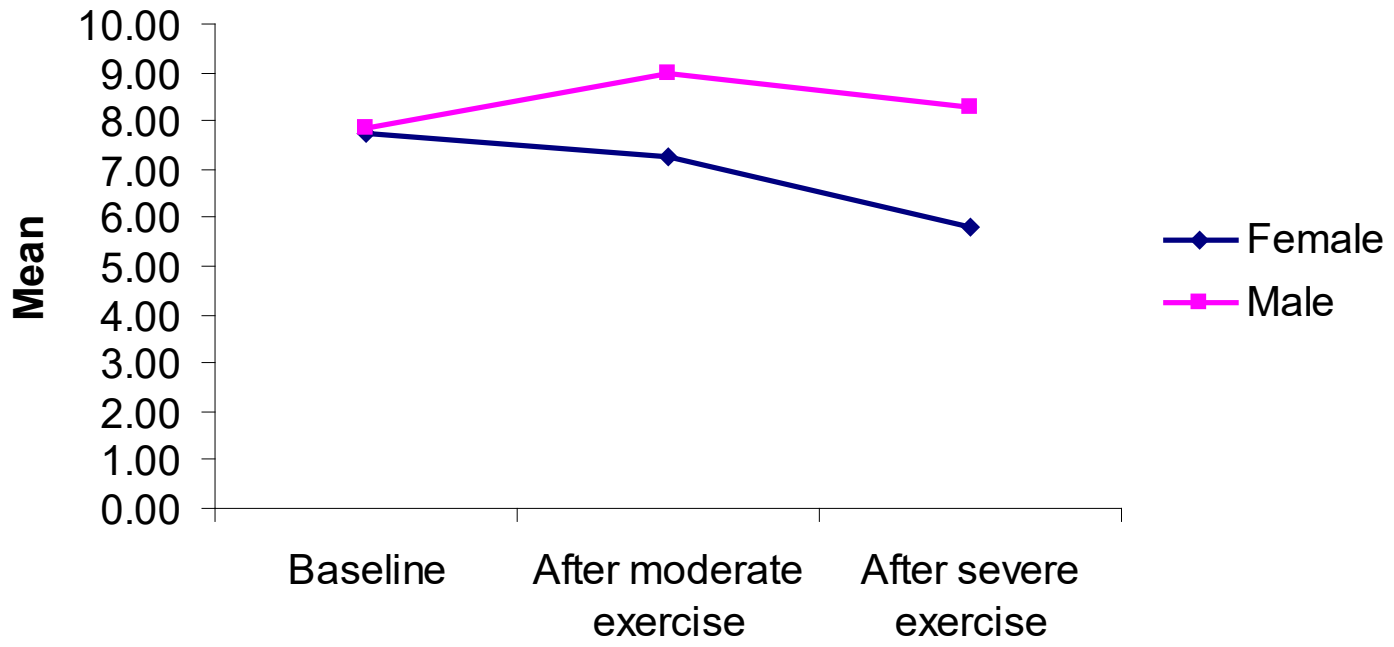

Figure 2. Mean serum cortisol level of males and females over the periods 
Table 4: Association between basic characteristics and outcome measures after moderate exercise $(\mathbf{n}=56)$

\begin{tabular}{|c|c|c|c|c|c|c|c|}
\hline \multirow{2}{*}{$\begin{array}{l}\text { Basic } \\
\text { characteristics }\end{array}$} & \multirow{2}{*}{$\mathbf{N}$} & \multicolumn{3}{|c|}{ HR (beats/min) } & \multicolumn{3}{|c|}{ Serum cortisol concentration $(\mathrm{mmol} / \mathrm{L})$} \\
\hline & & Mean \pm SE & t value & p value & Mean \pm SE & t value & p value \\
\hline $\begin{array}{l}\text { Age (yrs): } \\
\leq 20 \\
>20\end{array}$ & $\begin{array}{c}47 \\
9\end{array}$ & $\begin{array}{l}119.85 \pm 1.65 \\
121.89 \pm 1.53\end{array}$ & 0.53 & 0.598 & $\begin{array}{l}7.90 \pm 0.31 \\
9.35 \pm 0.54\end{array}$ & 1.91 & 0.061 \\
\hline $\begin{array}{l}\text { Sex : } \\
\text { Female } \\
\text { Male }\end{array}$ & $\begin{array}{l}28 \\
28\end{array}$ & $\begin{array}{l}122.93 \pm 2.03 \\
117.43 \pm 1.82\end{array}$ & 2.01 & 0.049 & $\begin{array}{l}7.28 \pm 0.41 \\
8.99 \pm 0.33\end{array}$ & 3.26 & 0.002 \\
\hline $\begin{array}{l}\text { Height }(\mathrm{cm}): \\
\leq 165 \\
>165\end{array}$ & $\begin{array}{l}32 \\
24\end{array}$ & $\begin{array}{l}120.72 \pm 2.21 \\
119.46 \pm 1.47\end{array}$ & 0.44 & 0.661 & $\begin{array}{l}7.63 \pm 0.36 \\
8.81 \pm 0.43\end{array}$ & 2.11 & 0.039 \\
\hline $\begin{array}{l}\text { Weight }(\mathrm{kg}): \\
\leq 60 \\
>60\end{array}$ & $\begin{array}{l}30 \\
26\end{array}$ & $\begin{array}{l}122.10 \pm 2.09 \\
117.96 \pm 1.77\end{array}$ & 1.49 & 0.143 & $\begin{array}{l}7.65 \pm 0.39 \\
8.69 \pm 0.40\end{array}$ & 1.87 & 0.067 \\
\hline $\begin{array}{l}\text { BMI }\left(\mathrm{kg} / \mathrm{m}^{2}\right): \\
<25 \\
\geq 25\end{array}$ & $\begin{array}{c}48 \\
8\end{array}$ & $\begin{array}{l}120.46 \pm 1.59 \\
118.50 \pm 2.54\end{array}$ & 0.49 & 0.630 & $\begin{array}{l}8.05 \pm 0.30 \\
8.62 \pm 0.85\end{array}$ & 0.69 & 0.495 \\
\hline $\begin{array}{l}\text { SBP }(\mathrm{mmHg}): \\
\leq 120 \\
>120\end{array}$ & $\begin{array}{l}44 \\
12 \\
\end{array}$ & $\begin{array}{l}120.52 \pm 1.66 \\
118.92 \pm 2.49\end{array}$ & 0.47 & 0.643 & $\begin{array}{l}8.13 \pm 0.34 \\
8.17 \pm 0.50\end{array}$ & 0.06 & 0.952 \\
\hline $\begin{array}{l}\mathrm{DBP}(\mathrm{mmHg}): \\
\leq 80 \\
>80\end{array}$ & $\begin{array}{l}44 \\
12\end{array}$ & $\begin{array}{l}120.64 \pm 1.63 \\
118.50 \pm 2.75\end{array}$ & 0.62 & 0.537 & $\begin{array}{l}8.19 \pm 0.33 \\
7.94 \pm 0.59\end{array}$ & 0.36 & 0.722 \\
\hline
\end{tabular}

Serum cortisol were found significantly associated to height.

Table 5: Association between basic characteristics and outcome measures after severe exercise ( $\mathrm{n}=56$ )

\begin{tabular}{|c|c|c|c|c|c|c|c|}
\hline \multirow{2}{*}{$\begin{array}{l}\text { Basic } \\
\text { characteristics }\end{array}$} & \multirow{2}{*}{$\mathbf{N}$} & \multicolumn{3}{|c|}{ HR (beats/min) } & \multicolumn{3}{|c|}{ Serum cortisol concentration $(\mathrm{mmol} / \mathrm{L})$} \\
\hline & & Mean \pm SE & t value & p value & Mean \pm SE & t value & p value \\
\hline $\begin{array}{l}\text { Age (yrs) : } \leq 20 \\
>20\end{array}$ & $\begin{array}{l}47 \\
9\end{array}$ & $\begin{array}{l}141.81 \pm 1.54 \\
146.89 \pm 5.70\end{array}$ & 1.19 & 0.240 & $\begin{array}{l}6.89 \pm 0.31 \\
7.83 \pm 0.86\end{array}$ & 1.18 & 0.244 \\
\hline $\begin{array}{l}\text { Sex : } \\
\text { Female } \\
\text { Male }\end{array}$ & $\begin{array}{l}28 \\
28\end{array}$ & $\begin{array}{l}143.89 \pm 2.56 \\
141.36 \pm 1.85\end{array}$ & 0.80 & 0.426 & $\begin{array}{l}5.82 \pm 0.33 \\
8.27 \pm 0.36\end{array}$ & 5.02 & $<0.001$ \\
\hline $\begin{array}{l}\text { Height }(\mathrm{cm}): \\
\leq 165 \\
>165\end{array}$ & $\begin{array}{l}32 \\
24\end{array}$ & $\begin{array}{l}141.22 \pm 2.23 \\
144.50 \pm 2.15\end{array}$ & 1.03 & 0.307 & $\begin{array}{l}6.23 \pm 0.37 \\
8.13 \pm 0.38 \\
\end{array}$ & 3.52 & $<0.001$ \\
\hline $\begin{array}{l}\text { Weight }(\mathrm{kg}): \\
\leq 60 \\
>60\end{array}$ & $\begin{array}{l}30 \\
26 \\
\end{array}$ & $\begin{array}{l}140.23 \pm 2.23 \\
145.38 \pm 2.13 \\
\end{array}$ & 1.66 & 0.104 & $\begin{array}{l}6.58 \pm 0.38 \\
7.58 \pm 0.44 \\
\end{array}$ & 1.73 & 0.090 \\
\hline $\begin{array}{l}\text { BMI }\left(\mathrm{kg} / \mathrm{m}^{2}\right): \\
\leq 25 \\
>25\end{array}$ & $\begin{array}{l}48 \\
8\end{array}$ & $\begin{array}{l}143.02 \pm 1.81 \\
140.25 \pm 1.97\end{array}$ & 0.61 & 0.543 & $\begin{array}{l}6.94 \pm 0.33 \\
7.70 \pm 0.62\end{array}$ & 0.91 & 0.366 \\
\hline $\begin{array}{l}\text { SBP }(\mathrm{mmHg}): \\
\leq 120 \\
>120\end{array}$ & $\begin{array}{l}44 \\
12\end{array}$ & $\begin{array}{l}142.32 \pm 1.76 \\
143.75 \pm 3.63\end{array}$ & 0.37 & 0.713 & $\begin{array}{l}6.93 \pm 0.35 \\
7.47 \pm 0.49\end{array}$ & 0.76 & 0.449 \\
\hline $\begin{array}{l}\text { DBP }(\mathrm{mmHg}): \\
\leq 80 \\
>80\end{array}$ & $\begin{array}{l}44 \\
12\end{array}$ & $\begin{array}{l}142.09 \pm 1.74 \\
144.58 \pm 3.75\end{array}$ & 0.65 & 0.521 & $\begin{array}{l}7.00 \pm 0.34 \\
7.21 \pm 0.58\end{array}$ & 0.29 & 0.771 \\
\hline
\end{tabular}

The serum cortisol level was found significantly associated to sex and height. 


\section{Discussion}

Serum total cortisol level after moderate and high intensity exercise showed that during moderate exercise, there was slight increase in cortisol level but it was of not very much significance. There are some divergent findings also and most literature has cited that a $\sim 60 \%$ exercise intensity threshold is necessary to elicit a significant increase in blood cortisol Davies \& Few(1973) ${ }^{[6]}$ and Hill et al $(2008)^{[7]}$. Similar observations have also been noticed by Suzan s. et al (2013) ${ }^{[8]}$ where they did not find any significant change after moderate and sever exercises. Bloom et al (1976) ${ }^{[9]}$ and Viru and Viru (2004) ${ }^{[10]}$ have observed that persons who are highly trained tend to have a higher intensity threshold to provoke an increase in cortisol.

The decrease in cortisol concentration in serum after severe exercise was not expected. Why this change occurred is unclear, but it could reflect the circadian pattern of cortisol secretion and/or a natural decline in the hormonal levels as a function of feedback regulation Few et al (1970) $)^{[11]}$ and Kerrigan et al (1993) $)^{[12]}$. The lack of a significant Cortisol response to the resistance exercise protocols may have been due to the time of blood sampling or the amount of rest periods between sets. Methodological flaws in the assay procedures are not a likely factor.

\section{Conclusion}

Serum total cortisol level of the subjects before exercise was $7.79 \pm 0.28 \mathrm{ng} / \mathrm{dL}$ (Mean \pm S.E) and after moderate exercise the serum cortisol was $8.13 \pm 0.28 \mathrm{ng} /$ $\mathrm{dL}$ (Mean \pm S.E) while after severe exercise the serum cortisol was $7.04 \pm 0.29 \mathrm{ng} / \mathrm{dL}($ Mean \pm S.E).

1. Serum total cortisol level of the male subjects before exercise was $7.87 \pm 0.42 \mathrm{ng} / \mathrm{dL}$ (Mean \pm S.E) and after moderate exercise the serum cortisol was $8.99 \pm 0.33 \mathrm{ng} / \mathrm{dL}($ Mean \pm S.E) while after severe exercise the serum cortisol was $8.27 \pm 0.36 \mathrm{ng} / \mathrm{dL}$ (Mean \pm S.E).

2. Serum total cortisol level of the female subjects before exercise was $7.72 \pm 0.37 \mathrm{ng} / \mathrm{dL}($ Mean \pm S.E) and after moderate exercise the serum cortisol was $7.28 \pm 0.41 \mathrm{ng} / \mathrm{dL}$ (Mean \pm S.E) while after severe exercise the serum cortisol was $5.82 \pm 0.33 \mathrm{ng} / \mathrm{dL}$ (Mean \pm S.E).

3. The serum cortisol level according to BMI ranged from ranged from 4.93 to $10.05 \mathrm{ng} / \mathrm{dL}$ with a mean of $6.76 \pm 0.86 \mathrm{ng} / \mathrm{dL}$ (Mean \pm S.E) in obese group $\left(\mathrm{BMI} \geq 25 \mathrm{~kg} / \mathrm{m}^{2}\right)$ before exercise and after moderate exercise the serum cortisol level ranged from 5.89 to 10.67 with a mean of $8.62 \pm 0.85 \mathrm{ng} / \mathrm{dL}$ (Mean \pm S.E) while after severe exercise the serum cortisol level ranged from 5.33 to $10.12 \mathrm{ng} / \mathrm{dL}$ with a mean of $7.83 \pm 0.62 \mathrm{ng} / \mathrm{dL}$ (Mean \pm S.E) 10.95 in obese group.

4. The serum cortisol level according to BMI ranged from ranged from 3.21 to $11.09 \mathrm{ng} / \mathrm{dL}$ with a mean of $7.97 \pm 0.29 \mathrm{ng} / \mathrm{dL}$ (Mean \pm S.E) in non-obese group (BMI $<25 \mathrm{~kg} / \mathrm{m}^{2}$ ) before exercise and after moderate exercise the serum cortisol level ranged from 3.14 to 10.95 with a mean of $8.05 \pm 0.30 \mathrm{ng} / \mathrm{dL}$ (Mean \pm S.E) while after severe exercise the serum cortisol level ranged from 5.15 to $11.16 \mathrm{ng} / \mathrm{dL}$ with a mean of $6.94 \pm 0.33 \mathrm{ng} / \mathrm{dL}$ (Mean \pm S.E) in nonobese group.

It was also observed that mean serum cortisol level was significantly higher in subjects with higher height $(>165 \mathrm{~cm})$ as compared to lower height $(\leq 165 \mathrm{~cm})(7.63$ \pm 0.36 vs. $8.81 \pm 0.43, \mathrm{t}=2.11, \mathrm{p}=0.039$ ).

Thus, according to our study, there is correlation of the serum cortisol levels according to the grades of exercise but still larger and long-term studies are needed to establish this association.

\section{Conflict of Interest: No}

\section{Source of Funding: Self}

Ethical Clearance: Given by Institutional Ethics Committee of the college.

\section{References}

1. Stampfer MJ, Hu FB, Manson JE, Rimm EB, Willett WC, Hu M and Rimm W. Primary Prevention of Coronary Heart Disease in Women through Diet and Lifestyle. New England Journal of Medicine. 2000; 343 (1): 16-22.

2. Carol Ewing Garber. American College of Sports Medicine Quantity and Quality of Exercise for Developing and Maintaining Cardiorespiratory, Musculoskeletal, and Neuromotor Fitness in Apparently Healthy Adults: Guidance for Prescribing Exercise, Medicine and Science in Sports and Exercise, 2011, 1334-1359.

3. BurtisA, Edward A. and David, B. Cortisol. T. Fundamentals of clinical chemistry (6th edition). 
2013; 754-780

4. Brooks GA, Fahey TD, White TP and Baldwin KM. Human Bioenergetics and Its Applications. Mountain View Exercise Physiology. Mayfield Publishing Company. 2000; 186-199.

5. Viru A, Viru M, Karelson K, Janson T, Siim K, Fischer $\mathrm{K}$ and Hackney AC. Adrenergic effects on adrenocortical cortisol response to incremental exercise to exhaustion. European Journal of Applied Physiology. 2007; 100: 241-245.

6. Davies CTM and Few JD. Effects of exercise on adrenocortical function. Journal of Applied Physiology. 1973; 35: 887-891.

7. Hill E, Zack E, Battaglini C, Viru M and Viru A. Exercise and circulation cortisol levels: the intensity threshold effect. Journal of Endocrinological. Investigation. 2008; 31: 587-591.

8. Suzan S and Mohammad-Ali K. Effects of aerobic exercise intensity on serum cortisol and testosterone in trained young men. Saudi J Sports Medicine. 2013; 13: 48-50.
9. Bloom SR, Johnson RH, Park DM, Rennie MJ and Sulaiman WR. Differences in the metabolic and hormonal response to exercise between racing cyclist and untrained individuals. Journal of Physiology. 1976; 258: 1-18.

10. Viru A and Viru M. Cortisol- essential adaptation hormone. International Journal of Sports Medicine. 2004; 25: 461-464.

11. Few JD, Frenkl R and Csalay L. Endocrine adaptation to regular muscular activity. Journal of Sports Medicine and Physical Fitness, 1970; 10: 1-7.

12. Kerrigan JR, Veldhuis JD, Leyo SA, Iranmanesh $\mathrm{A}$ and Rogol AD. Estimation of daily cortisol production and clearance rates in normal pubertal males by deconvolution analysis. Journal of Clinical Endocrinology and Metabolism. 1993; 76: 1505-1510. 